\title{
As Presunções na Teoria da Prova
}

\author{
Carlos Alberto Dabus Maluf \\ Professor Assistente do Departamento do Direito \\ Civil da Faculdade de Direito da USP
}

\begin{abstract}
SUMARIO: 1. Introducão - 2. A presunção no Direito Romano - 3. As presunçōes no Código Visigótico - 4. As presunçóes no Livro "Fiores de las Leyes" - 5. As presunções no Livro "Las Siete Partidas del Sabio Don Afomso" - 6. As presunçōes no Antigo Direito Lusitano e no Renuscimento - 7. As presunçōes no Direito Canônico - 8. As presunçōes no Regulamento 737 de 25-11-1850 - 9. A presuncão no Ć́digo de Processo Civil de 1939 - 10. A presunçāo no Código de Processo Civil de 1973 11. A presunøão no Direito Comparcudo - Direito frances, italiano, espanhol e alemão - 12. A presunsão na jurisprudência - 13. Conclusōes 14. Bibliografia.
\end{abstract}

\section{Introdução}

Afirma Mittermaier que as expressues indício e presunção são sinônimas, e que assim tanto os legisladores como os práticos as empregam indiferentemente.

Alguns autores, não obstante, têm estabelecido grandes diferenças.

Caravantes (in Tratado histórico, crítico y filosófico de los procedimientos em materia civil, t. II, p. 262) citado por Lopes-Moreno, D. Santiago (La prueba de indicios, Madrid, Lib. Victoriano Suarez, 1897), "entiende que la presunción surge del indicio, y que ni uno ni otra deben confundirse con la sospecha, que no es más que un ligero juicio».

O próprio Lopes-Moreno diz que atendendo à origem etimológica das palavras, se podem notar que expressam idéias distintas. Presunção, segundo o Dicionário da Real Academia, vem da palavra latina praesumptio, assim como esta deriva do particípio praesumptum do verbo praesumo, composto da preposição prae e do verbo sumo, que significa, em sentido literal, tomar antes. Indício vem de indicium, do verbo indico, e mais propriamente poderia considerar-se derivado do verbo induco, composto da preposição in e do verbo duco, ducere, levar a.

Segundo Valentin Silva Melero (La prueba procesal, Madrid, Revista de Derecho Privado, 1963, Tomo I), o termo latino presumere 
originariamente dá a entender um movimento corporal, e em muitas passagens da literatura jurídica clássica ou moderna, vem acompanhado da reprovação de ilicitude e atrevimento que implica em apoderar-se de algo.

O usurpador Juan que depois da morte do Imperador Honório subiu ao poder, recebeu o sobrenome de Preasumptor.

Prossegue Silva Melero, na obra citada, p. 112, que em um sentido estritamente jurídico, vem a significar «algo semejante a suponer o admitir en virtude y como consecuencia, de um labor intelectual difícil de explicar, por ser el resultado de la particular y privada formación cientifica y experimental de cada uno».

Moacyr Amaral Santos, em sua preciosa obra Prova Judiciária no Cível e Comercial, $3^{\text {a }}$ ed., vol. V, Max Limonad, 1968, p. 398, diz que opinião largamente difundida confere a presunção e indício sinonímia. Pensam desta maneira, segundo o renomado processualista, Carlo Lessona, Giorgio Giorgi e Marcel Planiol. Este ponto de vista escora-se no direito romano, onde não raro se encontram textos referentes à prova indiciária com o significado de prova por presunção.

Prossegue Amaral Santos sua ensinança dizendo que a teoria dominante, todavia, esclarece perfeitamente a relação entre indício e presunção.

Indício é o fato conhecido do qual se parte para o desconhecido, ou seja o fato conhecido em que se funda o raciocínio do juiz para chegar ao fato desconhecido; (Ramponi, Teoria Generale delle Presunzioni, 1890, e Coppola in Nuovo Digesto Italiano, Torino, Utet, 1939, vol. X). Diz este último no $n^{\circ} 4$ do verbete «Presunzione»: «La presunzione si distingue poi dall'indizio. Indicium, dal verbo indicare, manifestare, non è che il segno o l'argomento da cui si deduce ciò che si vuol provare. Anche nell'indizio, come nelle presunzioni, vi deve essere un rapporto di causalità tra il fatto noto (che indica, che manifesta una qualche cosa, che guida al fatto ignoto) ed il fatto ignoto, che si vuol provare. L'indizio è il fatto noto (circostanza indiziata), che si assume poi come vero, cioè si presume. La differenza tra la presunzione e l'indizio e in questo: che l'una prova su di un punto di fatto, e, se è presunzione juris et de jure, non ammette la prova contraria; l'altro non è che un elemento di convincimento, sempre discutibile e sempre oppugnabile da contrari argomenti».

Amaral Santos, obra citada, p. 399, diz que do indício como ponto de partida, por inferéncia se chega a estabelecer uma presunção. Por isso a prova por presunção constitui um silogismo, em que a premissa maior é o princípio geral, a premissa menor é o fato conhecido e a conclusão é o fato que se deseja conhecer. Donde o indício ser a causa, isto é, o fato conhecido, e a presunção o efeito, isto é, o conhecimento do fato antes ignorado. $\mathrm{Na}$ mesma ordem de idéias 
poder-se-ia dizer, com João Monteiro, que indício é o meio e a presunção um resultado (Processo Civil e Comercial, 1912).

Citando Lessona, Ramponi e Giorgi, o insigne Moacyr Amaral Santos, na mesma página diz que conquanto sejam dois conceitos distintos, justo é reconhecer-se que as duas palavras, na ordem lógica, se equivalem, por isso que significam o procedimento racional pelo qual de um fato conhecido e certo se infere por concatenação de causa a efeito, o fato desconhecido.

Sobre a matéria merece ser consultada a famosa obra intitulada A Lógica das Provas em matéria Criminal de autoria de escritor italiano Nicola Pramarino Dei Malatesta, trad. de J. Alves, $2^{\text {a }}$ ed.

\section{A presunção no direito romano}

No direito romano, príncipes e jurisconsultos submetidos que lhes eram casos particulares, ao resolvê-los, constantemente de fatos conhecidos e mediante raciocínio lógico extraíam presunções, nas quais fundavam seus julgamentos. Para assegurar a eficácia de fontes do direito atribuída aos rescritos dos príncipes e às respostas dos jurisconsultos, quando do procedimento formulário se passou para o da cognitio extraordinaria, «aconteceu o fenômeno notável de as presunções livremente acolhidas por aqueles príncipes e jurisconsultos serem elevadas a textos de lei e dignidade e eficácia de normas gerais» (C. Ferrini, Le presunzioni in diritto romano Opere, vol. III, Milano, 1929, pp. 417 e ss. citado por Virgilio Andrioli, in Novissimo Digesto Italiano, verbete «Presunzioni» (Diritto Romano, vol. XIII, 1966, p. 765).

Salienta Ferrini que essa transformação de presunções comuns em praesumptionis iuris coincidia com a mutação das idéias acerca das funções do julgador, «agora tornado um funcionário do Estado e cada vez a este mais ligado pelos laços da burocracia e dos regulamentos».

Em razão disso tais presunçōes, até então havidas como inferências de um fato conhecido para outro desconhecido, livremente colhidas e apreciadas pelo juiz, perderam essa natureza e se constituíram em preceitos legislativos, dos quais os relativos às presunções condicionais (iuris tantum) tinham por efeito inverter o natural ônus da prova entre as partes em juízo. Do exemplo romano se aproveitaram as legislações posteriores, que continuaram e ainda continuam a estabelecer tais inversões do ônus probatório.

Pela importância merece ser transcrita a lição de Andrioli, na obra e página acima citadas: «Il concetto giuridico della praesumptio va riportato necessariamente al momento in cui i giuristi si trovarono nella necessità di risolvere casi pratici, implicanti quaestiones facti, per l'addietro campo di elucubrazioni dei retori, sostituendosi, così ad essi. Il Donatuti, definita la praesumptio juris come «la norma giuri- 
dica che ordina di ammettere nel giudizio come provato un fatto la cui esistenza sia dubbia finchè non si sia avuta la prova del contrario».

O intuito dos romanos, transformando presunções comuns em presunções legais, era o de assegurar eficácia de fontes de direito aos rescritos dos príncipes e às respostas dos jurisconsultos. Os autores discutem a questão de saber se essa transformação operou-se na época bizantina ou a partir da aparição do processo extraordinário; uns vêem a presunção como «uma criação infeliz de Bizâncio»; outros entendem que ela nasceu no dia em que o juiz, de simples particular que era, se tornou «uin funcionário submetido cada vez mais aos regulamentos que lhe impunham seus superiores hierárquicos». Se se não pode fixar com precisão a data do nascimento, a filiação, entretanto é certa: a presunção legal representa a herança das presunções que o juiz estabelecia por instigação dos jurisconsultos; o papel destes últimos era tão importante que Quintus Mucius Scaevola pode ligar o seu nome à presunção referente à origem dos bens adquiridos pela mulher durante o casamento». É o que nos informa Roger Deccottignies (Les présomptions en droit privé, Paris, Pichun et Durand, 1950, $\mathrm{n}^{9} 12$, p. 30). Era a presunção muciana.

Semelhantemente, os legisladores, que os seguiram, também criaram presunções legais por motivos de ordem pública, que exige maiores garantias a determinadas relações jurídicas, isto é, para tutelar o interesse social, facilitando a prova, diminuindo o arbitrio do juiz na apreciação das provas ou na decisão de certas questões de fato.

\section{As presuncões no Código Visigótico}

Não obstante a grande influência eclesiástica sobre o Código Visigótico por influxo do Código Teodosiano (cf. Moacyr Lobo da Costa, 0 agravo no direito lusitano, Rio, Borsoi, 1974, p. 15), e o fato de se terem desenvolvido amplamente no direito canônico as diversas modalidades de presunções, o direito visigótico silencia sobre elas.

No Fuero Juzgo (versão castelhana da coleção original das leis visigóticas com o título de Liber Judicum ou Forum Judicum), no título sob o rubrica «Del iudez que quiere bien entender el pleyto que deve primeramientre fazer» (Fuero juzgo en latin y castellano, Madrid, Real Academia Española, 1815), encontra-se somente a insistência no sentido de que o juiz, para o perfeito conhecimento do pleito, deve saber a verdade dos testemunhos ou dos documentos e, na falta de provas testemunhais ou documentais, «venha o juramento se for mister».

Vamos transcrever literalmente o texto: «El iudez que bien quisiere oyr el pleyto, deve primeramientre saber la verdad de los testimonios, si los oviere en el pleyto, ó del escripto si lo y oviere, e non deve venir al sagramiento de las partes, nin las deve coniurar livianamientre. Ca esto semeia mayor derecho, que el escripto venga 
primeramientre por saber la verdad, é depues venga el iuramiento si fuere menester. Et mandamos que en los pleytos sea dado el sagramiento de las partes quando non pudier seer provado por testigos, ni por escripto» (Fuero Juzgo, cit. 2, 1, 21).

A importância do Código Visigótico na história das nossas instituições jurídicas é notória e indiscutivel.

Conforme a lição de Juan Antonio Alejandre (Temas de historia del derecho; derecho primitivo y romanización jurídica, Universidade de Sevilla, 1977, p. 135), o Códigó Visigótico foi realizado com assessoramento de São Bráulio, revisado no Concílio VIII de Toledo e promulgado em 654, sob o rei Flávio Recesvindo. O Código apresenta o relevante significado de constituir o diploma unificador dos estatutos romano e godo, além de que, na forma pela qual chegou até nós, engloba um grande número de Constituições de reis posteriores, até alguns anos antes da conquista árabe.

Sobre o significado do Código Visigótico merece ser lembrado o ensinamento do ilustre Prof. Rubens Limongi França, inserido no verbete Código Visigótico, publicado na Enciclopédia Saraiva de Direito, vol. 15, p. 490: «O monumento de maior importância para o estudo das origens do direito galo-ibérico, pois, com efeito, em Portugal, constitui lei até as Ordenações Afonsinas, publicadas em 1446, e, na Espanha, só foi revogado no século XIX».

Guilherme Braga da Cruz (o direito subsidiário na história do direito português, Coimbra, 1975, p. 181) lembra entretanto, que não menos importante é, a partir da primeira metade do século XII, o chamado renascimento do direito romano justinianeu e o concomitante movimento de renovação dogmática e doutrinária do direito canônico.

Sem determinar regras sistemáticas sobre as presunções, o Fuero Juzgo, todavia, no título sob a rubrica «De los escriptos que son dubdosos, cuemo deben seer provados por otros escriptos dessa misma mano», referindo-se aos escritos das pessoas que já faleceram, determina que se devem acatar os outros sinais e os outros escritos que elas fizeram e confirmar aquele escrito com os outros escritos: «Todos los escriptos é los pleytos que son fechos, é aquel que lo fizo fazer, é las testimonias son muertas, si parece su sennal dellos en el escripto, deve omne actar las otras sennales, é los otros escriptos que ellos fizioron, é confirmar aquel escripto con los otros escriptos. E deven abondar tres escriptos, ó quatro que sean semeiables daquel, por provar à aquel; fueras ende si los tiempos en que fuéron fechas las leyes, dizen que aquellos escriptos non deven valer» (Fuero Juzgo, cit. $2,5,14$ ).

\section{As presunções no livro «Flores de las leyes»}

No antigo livro Flores de las leyes, precioso compêndio de direito processual, sem dúvida uma das obras mais importantes da literatura 
jurídica medieval (Moacyr Lobo da Costa, ob. cit., p. 23), que em Portugal, logo desde o século XII, constitui uma das fontes subsidiárias de direito (Guilherme Braga da Cruz, ob. cit., p. 195), a rejeição das presunções como meios de prova aparece claramente no «Título das prouas de como se deuëen dar e quando seér recebudas», estabelecendo-se literalmente que as presunções não são para provar por si, servindo apenas para ajudar a provar o feito: "Todos as cousas se poden prouar per maneyras a primeyra e cõfysson da qual quer das partes. A segunda e por testigos. A terceyra e por cartas ou por enstrumentos publicos os enducios e as enndições e as prosonções nõ son pera prouar por sy, pero que aiuda a prouar o feyto» (ver Aloísio Surgik, verbete Presunção absoluta e relativa in Enciclopédia Saraiva de Direito, 60/391).

\section{As presunções no livro «Las siete partidas del sabio Don Afonso»}

No livro Las siete partidas del sabio Don Afonso, que alcançou grande aceitação em Portugal, a ponto de constituir-se numa importante fonte da primeira codificação portuguesa digna de menção, que foram as Ordenações Afonsinas (Guilherme Braga da Cruz, ob. cit., p. 201-2), provavelmente por influência já dos canonistas, uma vez que na época da promulgaģão da Lei das Sete Partidas (meados do século XIII) o direito canônico já gozava do maior prestígio, as presunções passam a merecer um especial tratamento no campo das provas.

Com efeito. Mister se faz esclarecer que no Título XIV da Terceira Partida ( $\ll$ De las prueuas e delas sospechas que los omnes aduzen en juyzio sobre las cosas negadas e dubdosas»), após a enumeração das maneiras diversas de se provar («Quantas maneras son de prueua»), passa-se especificamente à presunção, nos termos seguintes: «E a van ay otra natura de prouar, a que llaman presunpcion: que quiere tanto dezir, como grand sospecha que vale tanto en algunas cosas como aueriguamiento de prueua» (Las siete partidas del sabio Don Afonso, 3, 14, 8).

Como se pode notar pelos próprios termos ( $\mathrm{E}$ a vn ay otra natura de prouar»), a presunção assume aqui a natureza de prova.

Contudo, na seqüência, o mesmo texto deixa bem claro que não se deve ter por suficiente tão-só a prova de sinais e de suspeita, a não ser nos casos em que determina a lei: «Pero en todo pleyto non deue ser cabido solamente prueua de señales, e de sospecha: fueras ende en aquellas cosas que mandan las leyes deste nuestro libro: porque las sospechas, muchas vegadas non aciertan con la verdad» (Las siete partidas.. 3, 14, 8).

Depois dessas considerações e citações, chegamos às seguintes conclusões: a) no regime das Sete Partidas, a presunção é tida como prova; b) apesar de sua natureza probatória, ela não é suficiente 
por sí; c) é feita a distinção entre a presunção legal e a chamada presunção hominis.

Aliás, cumpre ressaltar que na glosa feita em latim, ao lado do referido texto, feita por Gregorio Lopez, insiste-se na distinção da presunção, dando-se, inclusive, uma definição da praesumptio hominis: Nota hic deffinitionem praesumptionis... praesumptio hominis est quidem conceptus causatus in mente ab aliqua probabili coniectura (a presunção hominis é na verdade o conceito causado na mente homana por alguma provável conjectura) (Las siete partidas. . 3, 14, 8, glosa).

Há também um trecho no qual se estabelece que não devem ser recebidas provas sobre as questões ou argumentos de filosofia: «Ca non deuen ser recebidas prueuas sobre las questiones, o argumentos de filosofia, porque tales contiendas como estas non se han de librar por fuero, nin por juyzio, si non por sabiduria de aquellos que se trabajan de saber, e de partir estas cosas. Otrosi, dezimos que aquella prueua deue ser tan solamente recebida en juyzio que pertenece al pley principal sobre que es fecha la demanda» (Las siete partidas... 3, 14, 7)

É curioso notar que ao lado deste texto, há uma glosa esclarecendo que a prova se faz não só por testemunhas ou instrumentos, mas também pela legítima confissão e também por presunção nos casos em que a lei expressamente determina: «Fit probatio non solum per testes, vel instrumenta: sed etiam per legitimam confessionem: et etiam per praesumptionem, ubi est expressum in alias non» (Las siete partidas $.3,14,7$, glosa).

\section{As presunções no antigo direito lusitano e no renascimento}

A despeito da grande influência exercida pelas Sete Partidas sobre o antigo direito lusitano e não obstante terem as compilações romano-canônicas passado a constituir a inesgotável fonte de soluçínes concretas dos problemas jurídicos a que os tribunais podiam recorrer para preencher os vazios de uma legislação incipiente, as presunções não tiveram realce nas obras legislativas e doutrinárias que antecederam as condificaçōes lusitanas, nem tampouco nestas últimas.

Realmente. Como ensina Moacyr Lobo da Costa (ob. cit., p. 11), no Livro de Leis e Posturas, antiga coletânea da legislação portuguesa, que foi sempre o ponto inicial de todas as pesquisas históricas sobre a legislação e costumes dos primeiros séculos da monarquia, não há qualquer exposição da matéria referente às presunções.

Somente uma ou outra passagem se refere eventualmente a elas, como e.g., na Ordenação de D. Afonso IV, que contém dezoito leis e várias outras resoluções sobre a forma pela qual se procederia nos processos. A lei referente aos feitos do crime assim estabelece: «Entom os ouujdores conssijrando a maneyra do fecto e a acusazom 
se sse proua, e a presençom quegenda he $E$ outrossi que pessõa he a do acusado podem no meter a tormento e pergunta lo per aquela quisa que o dereyto manda $E$ se confessar ou o confirmar sem tormento condanen o como dicto he $\mathrm{E}$ se o nom confessar e o fecto graue for o ascondudo detenham no pera saberem uerdade per alhur, ou pera o meter outra uez a tormento $\mathrm{E}$ todo esto podem os ouujdores fazer ssegundo as maneyras dos fectos ca em todos nom podia seer dada hua maneyra nenhua Regla» (Livro de Leis e Posturas, Lisboa, 1971, p. 237).

Como se verifica da passagem acima, o Livro de Leis e Posturas não considera as presunções como meios de prova, uma vez que, neste período da história, dispõe-se de outros meios para o descobrimento da verdade, inclusive a tortura, embora pela lei undécima se tenha estabelecido que a verdade é sabida pelas inquirições ou pela confissão de ambas as partes ou de cada uma delas: «E ssabuda a uerdade pelas enquerições que forem tomadas como dicto he ou per confissom danbas as partes ou de cada hua delas os sobre Jujzes os deuen liurar o preyto per sentença defenetjua» (Livro de Leis e Posturas, p. 232).

Com efeito. As Ordenações do Reino (Afonsinas, Manuelinas e as Filipinas), não tratam especificamente das presunçōes, a não ser indiretamente ou de passagem, como, por exemplo, no seguinte texto: «E se a parte, contra quem em juízo é oferecido algum instrumento, ou escritura pública, alegar e quiser provar que é falsa, ora o alegue por via de acusação, ou por via de exceção, o juiz, que do feito conhecer, a não receberá a isso, sem primeiro se obrigar e subscrever que, não provando a falsidade, haja a mesma pena que haveria aquele, que por sua parte oferece a dita escritura, se falsa fosse. E feita dita subscrição, lhe faça fazer declaração da razão da falsidade, em que parte é falsa, e de que maneira, e como entende provar essa razão de falsidade, e todas as outras circunstâncias porque melhor se possa entender e conhecer a dita falsidade, se é com verdade, se com malícia alegada. E logo sem outro intervalo faça vir perante si o tabelião, ou escrivão, que faz o instrumento, ou escritura, e alguma ou algumas das testemunhas nela nomeadas, para serem perguntadas sobre a verdade da escritura. E por qualquer presunção de falsidade, ou de malícia, que achar contra cada uma das partes, prenda logo aquele, contra quem achar a presunção, e não seja solto, até o feito ser determinado»; (Ordenações Filipinas, 3, 60, 5). Cumpre esclarecer que o texto acima citado tem como fonte as Ordenagoones Manuelinas, $(3,46,5)$.

No Renascimento, o retorno aos estudos dos textos romanos, diretamente, fora da Glosa, parece que surtiu efeito nos autores dessa época que escreveram sobre a matéria. Suas obras assumem enormes proporções. Lembraríamos neste período os nomes de Le Duaren (De probationibus, in Opera Omnia, 1746, v. 3, Cap. IV), Alciat (De praesumptionibus, in Tractatus universi juris, v. 5, t. 4) e a grande obra de Jacobus Menochius (De praesumptionibus, conjecturis, signis et indiciis, comentaria, Venetiis, 1617, 2 vols.). 
Cumpre ressaltar que Ramponi considera Menochius o pai da teoria da presunção. A sua obra não é de doutrina, mas uma coletânea de jurisprudência e das opiniões emitidas pelos autores da época sobre a matéria.

\section{As presunções no Direito Canônico}

Foi no Direito Canônico que as presunções, no terreno específico das provas, se desenvolveram e ramificaram nas várias modalidades.

Ludovico Engel em substanciosa obra (Collegium Universi Juris Canonici antheac juxta triplex juris objectum partitum, nune vero servato ordine Decretalium ... 8 8 ed. Beneventi, 1742, p. 146), segundo a ordem das Decretais de Gregório IX, dedica um extenso título às presunções. Define a presunção como sendo uma prova de coisa duvidosa ou controversa que se tira de outros fatos, esclarecendo que a presunção não prova imediatamente a intenção daquele em favor de quem se aduz, como ocorre com os documentos e as testemunhas, mas indiretamente, a modo de conseqüência.

Eis o texto original: «Praesumptio describi potest, quod sit rei dubiae seu controversae ex aliis positis desumata probatio. Dico, ex aliis positis; nam praesumptio non ita immediate et directe probt intentionem ejus, pro quo adducitur, sicut instrumenta et testes, sed tantum indirecte, seu potius in consequentiam, ut ex his, quaes modo sequentur, apparebit».

Engel faz a classificação, distinguindo as presunções em praesumptiones hominis e praesumptiones iuris, subdividindo as praesumptiones iuris em iuris tantum e iuris et de iure, explicando cuidadosamente cada uma delas (ob. cit., p. 146).

Pela importância, pedimos vênia para transcrever o texto latino: «Praesumptiones communiter in duas classes distinguuntur, ut scilicet aliae dicantur praesumptiones hominis et aliae juris, sed praesumptiones juris subdividuntur, quod aliae sint juris tantum, aliae juris et de jure».

Cumpre também ressaltar que, por mais insofismável que seja uma presunção, Ludovico Engel não admite que alguém possa ser condenado em causa criminal, apenas por presunção (ob. cit., p. 147).

No regime do Código de Direito Canônico atualmente vigente, as presunções encontram-se regulamentadas a partir do cânon $\mathbf{n}^{\circ}$ 1.825: "Praesumptio est rei incertae probabilis coniectura; eaque alia est iuris, quae ab ipsa lege statuitur; alia hominis, quae a iudice coniicitur. $\S 2$. Praesumptio iuris alia est iuris simpliciter, alia iuris et de iure». Ou em vernáculo: Presunção é a conjectura provável de uma coisa incerta; pode ser iuris - de direito, que é a determinada pela mesma lei, e hominis - de homem, que é a formada pelo juiz. $\S 2$. A presunção de direito pode ser de direito simplesmente e iuris et de iure - de direito e por direito. 
Em continuação, nos cân. 1.826 e seguintes regula-se a matéria detalhadamente, estabelecendo-se que, contra a presunção simplesmente de direito, se admite prova tanto direta como indireta, ao passo que, contra a presunção de direito e por direito (iuris et de iure), somente indireta, ou seja, contra o fato em que se funda a presunção (cân. 1.826).

Se a lei não diz claramente que a presunção é iuris et de iure, entende-se que é iuris tantum. Contra esta se admite não só a prova indireta, consistente em negar o fato indiciário, mas também a prova direta, que consiste em admitir aquele fato é negar sua conexão com o fato incerto que se pretende demonstrar. Contra a presunção declara iuris et de iure não se admite a prova direta, mas tão-somente a indireta. Isto nos informa Miguelez-Alonso Cabreros (Código de Derecho Canónico bilingue y comentado, Madrid, MCMLI, p. 679).

Além do mais, quem tem em seu favor a presunção de direito está relevado da obrigação de provar, que recai sobre a parte contrária, e, se esta não prova, a sentença deve ser proferida em favor da parte a quem favorece a presunção; (cân. 1.827).

Ensinam os canonistas modernos que presunção é a conseqüência lógica que a lei ou o juiz deduzem de um fato certo em ordem a provar outro incerto, fundando-se na conexão que entre ambos os fatos geralmente costuma mediar. $O$ fato que serve de base à presunção chama-se indício (Miguelez-Alonso Cabreros, ob. cit., p. 679). Contudo, preceitua o cân. 1.828 que o juiz não pode formar presunções que o direito não estabelece, a menos que as baseie em algum fato certo e determinado, relacionado diretamente com aquele que é objeto da controvérsia.

Muito embora no Código de Direito Canônico se encontrem diversos exemplos de presunção legal, como se depreende pela leitura dos câns. 16, $\S 2,63, \S 2,1.015, \S 2,1.814$ e 1.904, § 1, Fernando Della Rocca («De morali certitudine in sententia canonica», in Saggi di diritto processuale canonico, Padova, Cedam, 1961, pp. 275-6) faz questão de esclarecer que o princípio da prova legal é muito mais reprimido no processo canônico que nos processos regidos pelas leis dos Estados, lembrando que no processo canônico, por tradição, sempre prevaleceu a chamada probatio libera ou probatio moralis, sendo poucas as provas legais, encontrando-se entre elas a praesumptio iuris et de iure (cân. 1.826) e outras provas legais «singulares» expressamente indicadas nos câns. 1.747, $n^{\circ} 1,1.191, \S 2,1.816,1.836, \S 2$, $1.836, \S 4$ etc.

No entanto, esclarece Fernando Della Rocca que o processo de formação da certeza moral deve evoluir dentro de certos limites, de acordo com um roteiro, e tal roteiro é representado pelas regras processuais e principalmente pelos elementos constantes dos autos (ob. cit., p. 278), devendo-se observar, segundo ele, que, nos termos do cân. 1.869, § 3 («probationes autem aestimare judex debet ex sua 
conscientia»), confirma-se pelo legislador eclesiástico o fato de que o princípio da prova legal é uma exceção no direito processual canônico (ob. cit., p. 279).

Da pesquisa até aqui feita, pode-se perceber claramente que as presunçōes, enquanto vinculadas às provas, na verdade, ramificaram-se e multiplicaram-se principalmente no seu terreno mais fértil, que foi o direito canônico.

Outrossim, cumpre ressaltar que a finalidade principal do direito canônico não é outra senão preparar o ser humano para a vida eterna. Por força deste objetivo espiritual que constitui o princípio fundamental de todo o direito canônico, sacrificam-se quaisquer outros princípios que se lhe contraponham, ainda que assentados sem divergência na doutrina processual.

E para provar nossa assertiva, vamos mencionar um caso concreto que está estreitamente ligado ao tema das presunções: o princípio da coisa julgada.

No direito canônico, contrariamente do que sucede com os direitos processuais civis, a regra da coisa julgada fica sujeita a uma grave exceção no ensinamento de Fernando Della Rocca (ob. cit., p. 3), pois várias causas são subtraídas à coisa julgada e podem ser repropostas em juizo. Entre elas, as causas matrimoniais, cujas sentenças nunquam transeut in rem judicatum (cân. 1.903). O direito divino sobre o qual repousa o instituto do matrimônio, a indissolubilidade do vínculo, em suma a natureza sacramental do próprio matrimônio consolidam e valorizam o motivo da salvação eterna, que é o objetivo espiritual da Igreja, não permitindo o trânsito em julgado, assim como, de uma maneira genérica, nunca transitam em julgado as causas sobre o estado das pessoas.

\section{As presunções no regulamento $73 \%$ de 25-11-1850}

Art. 184: «As presunções legais ou são absolutas, ou condicionais».

Art. 185: «São presunções legais absolutas os fatos, ou atos que a lei expressamente estabelece como verdade, ainda que haja prova em contrário, como a coisa julgada».

Art. 186: «Presunção legal condicional é o fato, ou o ato que a lei expressamente estabelece como verdade, enquanto não há prova em contrário. Estas presunções dispensam do ônus da prova àquele que as tem em seu favor».

Por sua vez, o Código de Processo do Estado de São Paulo tratou da matéria em seus arts. 304 e 305 . Não faremos comentários sobre esses dispositivos legais do passado, eis que nossa maior preocupação é analisar a matéria nos Códigos de 1939 e de 1973. 


\section{A presunção no Código de Processo Civil de 1939}

Muita confusão existe a respeito das presunções e dos indícios, que o Código de Processo Civil de 1939 incluiu entre as provas, e colocou como epigrafe do capítulo VI, título VIII, do Livro II.

Explica François Gorphe, citado por José Frederico Marques nas Instituięões de Direito Processual Civil, vol. III, Forense, Rio, 1959 que a prova por indícios, presunções e circunstâncias é de grande extensão e mal definida, consistindo ela em «recolher e interpretar todos os fatos ou circunstâncias que possam levar à descoberta da verdade». Sem embargo disto, não há denominação bem precisa sobre essa prova. «Os civilistas preferem falar de presunções», enquanto que os criminalistas usam da expressão indícios e «les juristes anglais ou américains de circonstances» (L'Appréciation des Preuves en Justice, 1947, p. 246).

A doutrina discute as relações entre a presunção e a prova, no intuito de averiguar se entre elas existe realmente uma relação de dependência.

No que concerne às suas relações externas, é pacífica a doutrina, porque, apoiando-se num fato conhecido, a presunção supõe necessariamente a prova direta deste fato, de que ela resulta como prova indireta.

Segundo Pedro Batista Martins em seus Comentários ao Código de Processo Civil, $2^{\text {a }}$ ed., Rio, Forense, 1960, vol. III, t. $2^{\circ}$, p. 69, as teorias, entretanto, se multiplicam quando se trata de analisar as relações intrínsecas entre a presunção e a prova. Dessas várias teorias emerge, em primeiro plano, a da sub-rogação, segundo a qual a presunção não é uma prova, mas dela apenas faz as vezes, na impossibilidade, ou na extrema dificuldade, de produção da prova direta do fato.

De acordo com uma outra teoria, a diferença única que existe entre a presunção e a prova é que esta gera a certeza moral e aquela apenas a probabilidade.

Prossegue aquele autor: «Uma terceira corrente, distinguindo embora entre ambas, só lhes encontra uma diferença: a presunção ao contrário do que ocorre com a prova, é a conseqüência resultante de um fato que não tinha especialmente por fim estabelecer a verdade do outro fato que vem revelar e que era, precisamente, o fato que se deveria provar.»

Rezava o art. 251 do Código de Processo de 1939: «A prova contra presunção legal será sempre admitida, salvo quando a própria lei a excluir».

Digna de menção é a definição de Neves e Castro em sua Teoria das Provas, nº 333: "Presunção é a consequiência ou ilação, que a lei 
ou o juiz tira de fato conhecido, para decidir a existência de outro, que se pretenda provar».

Dividem-se as presunções: a) legais absolutas, ou juris et de jure; b) legais condicionais, ou juris tantum; c) comuns ou hominis.

São presunções legais absolutas (juris et de jure) os fatos ou atos, que a lei expressamente estabelece como verdade, ainda que haja prova em contrário (Reg. 737, art. 185).

São chamadas juris, porque foram introduzidas pela lei, e de jure, porque sobre tal presunção a lei estabelece um direito constante e a considera como verdade. Esta é a opinião de Fabreguettes, em Lógica das Provas, p. 205, nota 4, citado por Carvalho Santos no Código de Processo Civil Interpretado, vol. III, 3 $3^{\text {a }}$ ed., 1946.

As presunções dessa natureza não admitem prova em contrário, só se verificando em casos expressos em lei.

Não se exige que haja uma lei especial determinando a natureza da presunção juris et de jure, mas em todo caso, como excepcionais que são, somente quando a lei determina, ou proíbe expressamente qualquer prova em contrário, poder-se-á admitir tenham as presunções essa natureza.

Em caso de dúvida, o melhor critério, como bem observa Câmara Leal, citado por Carvalho Santos, obra citada, pp. 401/402 será perquirir o motivo que levou o legislador a estabelecer a presunção e verificar se ela obedeceu a uma razão de ordem pública ou de interesse coletivo, ou se teve por fim assegurar a estabilidade de uma relação de ordem geral, para, em qualquer desses casos, ou em outros da mesma relevância, concluir pelo caráter absoluto da presunção.

Vejamos agora a presunção legal condicional. É o fato ou o ato que a lei estabelece expressamente como verdade, enquanto não há prova em contrário. Estas presunções dispensam do ônus da prova aquele que as tem em seu favor (Regulamento 737, art. 186).

A conseqüência desta última modalidade cifra-se na inversão do ônus da prova. O Código de 1939, nos dois parágrafos do art. 209, contém as seguintes regras relativas à distribuição do onus probandi: a) se o réu, na contestação, negar o fato alegado pelo autor, a este incumbirá o ônus da prova; b) se o réu, reconhecendo o fato constitutivo, alegar a sua extinção, ou a ocorrência de outro que lhe obste aos efeitos, a ele cumprirá provar a alegação.

Caem, entretanto, sem aplicação, estas regras, sempre que a lei estabelece uma presunção iuris tantum, isto é, uma presunção condicional da existência de um fato. Em tal caso, o fato se considerará existente até que o interessado, não importe se o autor ou o réu, apresente prova em contrário.

Segundo Pedro Batista Martins, obra citada, p. 71, as presunções legais são idênticas, no concernente à sua gênese lógica, porque todas 
elas se apresentam como ilações deduzidas de um fato conhecido; mas relativamente à sua funģão judiciária são de tal modo diversas, que, como observa Lessona, a pouquíssimas se reduzem as normas comuns às três espécies. Conforme a lição de Carlo Lessona (Trattato delle Prove in Materia Civile, $3^{\text {a }}$ ed., vol. $5^{\circ}$, pp. 135-137) entre os caracteres comuns pode registrar-se: $1^{\circ}$ ) a circunstância de implicarem todas elas o cerceamento do arbítrio do juiz na apreciação da prova; $2^{\circ}$ ) todas elas importam em dispensar da prova a parte a favor da qual se haja estabelecido a presunção; $3^{\circ}$ ) finalmente, não haverá presunção legal, de qualquer natureza, que não se assente numa disposição especial de lei.

As presunções legais absolutas, também juris et de jure, isto é, aquelas contra as quais não se admite a prova em contrário, não são propriamente presunções, no sentido lógico-jurídico, no dizer de Pedro Batista Martins, obra citada, p. 72, mas disposições imperativas da lei.

Para demonstração dessa tese, Lessona, obra cit., p. 179 menciona os dois exemplos seguintes: $1^{\circ}$ ) Quando a lei declara a incapacidade do menor de 21 anos para o exercício dos direitos, esta norma se funda na presunção de uma incapacidade natural absoluta de todas as pessoas que ainda não tenham atingido aquela idade: mas a presunção, fundada na lógica e na experiência, assume a forma de uma disposição absoluta. E nenhum menor poderá arrogar-se o exercício dos direitos, que lhe é negado pela lei, provando que, ao contrário da presunção, tem plena capacidade para tal exercício; $2^{\circ}$ ) Igualmente, quando a lei exige forma especial para determinados atos, esta sua vontade parte da presunção de que, sem a observância daquela forma, o ato não pode realizar-se sem prejuízo da segurança das relações jurídicas. Baldada seria, em tais casos, a prova de que a realização do ato por outra forma não constituiria perigo para a segurança dos direitos.

As presunções legais condicionais, como já se disse, têm como característica principal a inversão do onus probandi. A lei, para assim estatuir, considera: 10) a impossibilidade ou a extrema dificuldade que haveria, para aquele em favor de quem estabelece a presunção, de produzir a prova direta do fato probandum; $2^{\circ}$ ) a facilidade que há para o interessado na produção da prova contrária ao fato presumido; $3^{\circ}$ ) a existência de relações de causalidade, ligando os fenômenos uns aos outros, de modo tal que a experiência nos ensina que, dado um certo fato, outro possivelmente lhe seguirá.

A presunção legal relativa não importa, como sustenta certa corrente doutrinária, em dispensa do ônus da prova.

Segundo Pedro Batista Martins, obra citada, p. 73, o que ocorre é apenas a facilitação da prova, pois que se desobriga a parte de provar diretamente o fato probandum, contentando-se a lei com a prova de um outro fato, do qual se possa inferir o primeiro.

São muito comuns na nossa legislação as presunções juris tantum, podendo ser mencionadas como exemplos: a) a da legitimidade dos 
filhos, concebidos na constância do casamento (art. 338 do CC); b) a morte do ausente, que se presume após 30 anos de seu desaparecimento (art. 482 do $\mathrm{CC}$ ); c) a boa fé, que se presume no possuidor com justo título (art. 490 do $\mathrm{CC}$ ); d) a presunção de pagamento resultante da entrega do título, etc. (art. 945 do CC), etc.

Pontes de Miranda mencionado por Carvalho Santos, obra citada, p. 402, ensina que, em nosso direito, há também as presunções legais intermediárias, de que fala Alves Moreira, as quais se verificam quando a lei, sem excluir completamente a prova em contrário, só a admite em condições especialíssimas, citando exemplos, como os casos dos arts. 333 e 339 do CC brasileiro.

Aubry et Rau e outros tratadistas referem-se, também, a essa espécie intermediária de presunções.

Contudo, a categoria de presunções mistas não é reconhecida por todos os escritores. Há quem entenda que tais presunções mais se aproximam das juris et de jure. Nesse sentido Pontes de Miranda, em suas anotaçōes a Neves e Castro: «O caráter de tais presunções é, contudo, o das presunções juris et de jure, razão por que preferimos denominá-las presunções de jure intermédias».

Parece todavia, acentua Amaral Santos, Prova Judiciária, p. 477, que as presunções mistas mais se assemelham às condicionais. $\mathrm{Na}$ verdade entre umas e outras há um ponto relevante de contato: podem ser contrariadas. Distinguem-se, porém, porque às condicionais pode ser oposta toda e qualquer prova, enquanto que contra as mistas se permitem tão-somente aqueles meios de prova especialmente referidos e previstos na própria lei.

Como diz Pedro Batista Martins nos Comentários, p. 73, a prova contrária é limitada, pela própria lei que estabelece a presunção a uma determinada espécie de prova.

$\mathrm{O}$ art. 340 do $\mathrm{CC}$, por exemplo, ao presumir a legitimidade do filho concebido na constância do casamento, restringe, ao mesmo tempo, a prova contrária, que deverá versar: $1^{\circ}$ ) sobre a impossibilidade física do marido de coabitar com a mulher, nos primeiros 121 dias, ou mais, dos 300 , que houverem precedido ao nascimento do filho, e $2^{\circ}$ ) sobre o fato de se acharem os cônjuges legalmente separados ao tempo da concepção. Digna de nota é a lição de Jorge Americano nos Comentários ao Código de Processo Civil do Brasil, $2^{\mathrm{a}}$ ed., Saraiva, São Paulo, 1958, vol. 1ํ, p. 393: «Presunção legal absoluta é, pois, a conclusão que a lei impõe ao julgador para valer definitivamente como verdade, desde que se verifiquem as premissas supostas na lei. Presunção legal condicional é a conclusão que a lei sugere ao julgador, verificadas as premissas nela supostas, para valer como verdade, se se não apresentar prova convincente em sentido diverso».

Prossegue o festejado autor dizendo que a determinação das presunções absolutas pertence ao direito substantivo. Distinguem-se ex- 
ternamente das presunções legais condicionais, pela forma peremptória com que a lei as exprime. Em regra, as presunções legais são condicionais, e excepcionalmente são absolutas, nos casos expressos, ou ainda, nos implícitos, quando de outra forma não se possa entender.

Quanto às presunções comuns, também denominadas de fato, ou hominis, convém desde logo, esclarecer que não são estabelecidas na lei. Ao contrário, fundam-se naquilo que ordinariamente acontece (Reg. 737, art. 187). Dá-se-lhes a denominação de presunções hominis por serem presunções de que o juiz, como homem, «se utiliza no correr da lide para formar sua convicção como faria qualquer raciocinador fora do processo». Esta é a explicação de Chiovenda em seus Principi di Diritto Processuale Civile, $4^{\text {a }}$ ed., p. 853, que a seguir acrescenta: "Quando, segundo a experiência que temos da ordem normal das coisas, um fato constitui causa ou efeito de outro, ou de outro se acompanha, nos é conhecida a existência de um dos dois, presumimos a existência do outro. A presunção equivale, pois, a uma convicção fundada sobre a ordem normal das coisas».

Para Manuel de La Plaza, citado por José Frederico Marques, Instituições, p. 486, a presunção hominis que se inscreve entre as provas críticas, dá margem a que o juiz atue livremente na escolha do «fato que há de servir de base para formular a presunção», e ainda, sob certo aspecto, «para deduzir suas consequiências».

Segundo Carvalho Santos, Códligo de Processo Interpretado, p. 403, duas condições são exigidas para que as presunções comuns sejam admitidas: uma, de direito, outra, de fato. E essencial: 10) que seja possível a prova por testemunhas; $2^{\circ}$ ) que as presunções sejam graves, precisas e concordantes. Prossegue o renomado jurista esclarecendo «que não sendo admissível a prova testemunhal, não será possível fazer a prova por presunções. Pelo menos em regra, porque no sistema do nosso Código (de 1939) como sabemos, poderá o juiz livremente formar a sua convicção o que não impede, portanto, que ele deixe de lado essas regras doutrinárias, a não ser que se trate de prova da essência ou da substância do ato».

Continua o saudoso escritor: «O que se exige, também, é que as presunções sejam graves, precisas e concordantes. São graves, quando as relações do fato desconhecido com o fato conhecido são tais, que a existência de um estabelece, por indução necessária, a existência do outro. São precisas, quando as induções, resultando do fato conhecido, tendem a estabelecer direta e particularmente o fato desconhecido e contestado. São concordantes, enfim, quando, tendo todas uma origem comum ou diferente, tendem, pelo conjunto e harmonia, a firmar o fato que se quer provar (Laurent, e Labori, obra cit., vol. Preuve, $n^{9}$ 522).

Ao que parece, Carvalho Santos, colheu esta lição de Fabreguettes in Lógica Judiciária e a Arte de Julgar, tendo sido um dos capítulos publicados na Revista de Direito Civil, Comercial e Criminal, 
dirigida pelo Dr. Antonio Bento de Faria, vol. 39, Fasc. II, fevereiro de 1916, sob o título - «Da prova indireta - Das presunções legaes humanas».

Quando estivermos analisando o direito comparado, e em particular o direito francês, voltaremos a abordar tal estudo de Fabreguettes.

Jorge Americano, em seus Comentários, p. 393, diz que «quando a construção é um produto livre do espírito, temos a presunção comum; e esta é a conclusão do que sói acontecer, tirada pelo julgador, dos fatos provados na causa, para valer como verdade se não se provar coisa diversa».

O número de presunções, ensinam os doutores, necessário para constituir uma prova convincente, fica entregue ao arbítrio do juiz. Pode ele, por conseguinte, fundar sua decisão numa só presunção, quando lhe parecer suficiente para firmar sua convicção. Com as presunções acontece o mesmo que com as testemunhas: pesam-se, mas não se contam. Uma presunção pode, embora isolada, ser mais poderosa que várias presunções reunidas, ainda aqui se revelando a repulsa do direito moderno pelo antigo adágio: testis unus, testis nullus (Laurent Principes de Droit Civil, $n^{9} 637$ e Demolombe, Cours de Code Napoleon, $\mathrm{n}^{\circ}$ 245).

Há entre as presunções legais e as presunções simples um traço comum, pois que ambas são resultados da indução que, partindo do fato conhecido, infere o desconhecido. Mas, entre ambas, há igualmente caracteres diferenciais que nitidamente as distinguem.

Segundo a lição de Pedro Batista Martins, obra citada, p. 74, as presunções simples dependem da livre avaliação do juiz, que as aprecia à luz de critérios subjetivos, ao passo que as presunçóes legais se impõem ao seu exame de modo necessário e imperativo.

Vejamos agora, o art. 252 do Código de Processo de 1939 que rezava in verbis: «O dolo, a fraude, a simulação e, em geral os atos de má fé, poderão ser provados por indícios e circunstâncias».

Nem o dolo, nem a fraude, nem a simulação, nem, em geral, os atos de má fé se presumem. Devem ser provados, para que o juiz admita a existência de tais vícios. Mas, como em geral todo ato que envolve má fé, é praticado secretamente, afastada a possibilidade de qualquer testemunho, admite a lei uma certa liberdade quanto à sua prova, no sentido de facilitá-la, pois, não seria justo que, da dificuldade de prova, deliberadamente procurada, pudesse a parte que agiu de má fé tirar partido (conforme Carvalho Santos, obra cit., p. 405).

$\dot{E}$ assentado pelos tratadistas que, em matéria de fraude, e, em geral, quanto à prova de todo ato em que se procura iludir a outrem, admite-se como de grande relevo, não a prova incisiva, mas a certeza inferida de indícios e circunstâncias. Por isso mesmo que o ato é 
rodeado das máximas cautelas para não ser conhecido ou para ser interpretado sob prisma diverso do verdadeiro, o processo da investigação e julgamento deve ser livre de entraves ou preceitos formais, que só serviriam para que o dolo ficasse encoberto.

Como diz Jorge Americano, obra citada, p. 395 - «se é recomendável a maior liberdade no exame e crítica dos fatos, na pesquisa de todos os elementos de convicção presentes ao magistrado, cumpre-lhe revestir-se, porém, de critério superior às causas de erro, às vezes, dirigem o pesquisador apaixonado pelas próprias investigações, para que não tome por indícios convincentes certos fatos que, desapaixonadamente observados, nada mais revelam senão a boa fé presumível em todos os atos humanos».

E conclui Americano: «Se da combinação dos elementos em estudo transparece o conluio ou a má fé, dela não se pode exigir prova incisiva. O fato de natureza oculta foge à luz, procurando vestir-se sob formas irreconheciveis, e a prova direta jamais pode trazer contingente de relevo à elucidação do dolo ou da fraude».

Passemos agora ao art. 253 do CPC de 1939, que assim dizia: «Na apreciação dos indícios, o juiz considerará livremente a natureza do negócio, a reputação dos indiciados e a verossimilhança dos fatos alegados na inicial e na defesa».

O juiz tem ampla liberdade de dar ao indício o valor probante que lhe parecer cabível. Tudo dependendo das circunstâncias. Como acentua Carvalho Santos, obra cit., p. 406, «não é outra coisa que o Código aqui dispõe, afastando-se daquelas legislações que expressamente dispunham que os indícios, sendo graves e concordantes, fazem prova plena». Prossegue Carvalho Santos esclarecendo que não quer isso dizer que o juiz não deva se orientar, buscando conhecer o ensinamento da doutrina, mas certo de que a este não ficará adstrito, quanto à formação de sua convicção, na apuração do exato valor probante que deva dar aos indícios provados nos autos.

\section{A presunção no Código de Processo Civil de 1973}

Ao contrário do Código de 1939, que dispensou um Capitulo às presunções e aos indícios, o Código vigente tratou da matéria em apenas um artigo (334) que reza: «Não dependem de prova os fatos: IV - em cujo favor milita presunção legal de existência ou de veracidade».

Não nos deteremos muito na análise desse dispositivo, eis que já expusemos com alguma minúcia as ponderações doutrinárias, quando estudamos o Código de 1939. Mas, por uma questão de boa técnica, faremos algumas considerações a respeito do assunto.

Uma das características das praesumptionis juris, está no seu efeito: dispensa do ônus da prova aquele que as tem em seu favor. 
Por outras palavras, é o que preceitua o art. 334, IV do Código de Processo vigente.

$\dot{E}$ preciso que se entenda essa regra nos seus devidos limites. Ela não atribui à parte, que invoca uma presunção legal, o benefício de poder ficar inativa, ou como adverte Bonnier, citado por Moacyr Amaral Santos nos Comentários ao Código de Processo Civil, Rio, Forense, 1976 , vol. IV, p. 49, ela não quer dizer que «aquele que invoca uma presunção legal nada tem que provar». Quem a invoca deverá necessariamente demonstrar que está na situação de poder invocá-la.

Por ser legal, a presunção não deixa de ser uma presunção, e, portanto, constituída de três elementos: $1^{\circ}$ ) o fato conhecido; $2^{\circ}$ ) 0 fato desconhecido; $3^{\circ}$ ) o nexo de causalidade entre o fato conhecido e o fato desconhecido. O fato desconhecido é havido como provado pela lei, que também tem como reconhecido e preestabelecido o nexo de causalidade, mas isto e aqui somente se verificam quando quem invoca a presunção faça provado o fato do qual ela dimana, isto é, o fato conhecido.

Aliás, nesse sentido é a lição de Coppola, no verbete «Presunzione», no Nuovo Digesto Italiano, $\mathrm{n}^{\circ}$ 8, Torino, Utet, 1939, Vol. X: «Ogni presunzione è costituita da tre elementi necessari: $1^{\circ}$ il fatto noto; $2^{\circ}$ il fatto ignoto; $3^{\circ}$ il nesso di causalità tra il fatto noto ed il fatto ignoto. Il nesso di causalità è riconosciuto e prestabilito dalla legge; il fatto ignoto è ritenuto provato dalla legge stessa; per il fatto noto non vi è differenza di prova».

Digna de nota é a lição de Couture, em seu Fundamentos del Derecho Procesal Civil, $n^{\circ}$ 91, esclarecendo que «uma presunção supõe o concurso de três circunstâncias: um fato conhecido, um fato desconhecido e uma relação de causalidade. O que na realidade fica fora do campo do objeto da prova são os dois últimos desses elementos: o fato desconhecido e a relação de causalidade. Porém nada subtrai da atividade probatória a demonstração do fato em que a presunção deve apoiar-se».

«De conseguinte - escreve Aguilera de Paz citado por Moacyr Amaral Santos, Comentários, p. 50 - é indispensável que o fato-base da presunção (o fato auxiliar, o indício) esteja plenamente provado», e isso é da «essência e do fundamento das presunções, porque estas qualquer que seja a sua classe, necessitam partir de um fato conhecido, vale dizer de um fato provado, do qual possa inferir-se o fato desconhecido havido como certo pela presunção». Ora - continua o mesmo autor - se o fato-base tem que ser provado, não pode haver dúvida alguma de que sua prova compete ao favorecido pela presunção», o qual terá que produzi-la para poder beneficiar-se desta.

Assim, por exemplo, se um dos cônjuges, na ação de desquite (hoje, separação judicial pela nova lei do divórcio de dezembro de 1977), alegar em seu favor a presunção do perdão contida no art. 317, 
parágrafo único do $\mathrm{CC}$ - pelo qual o adultério se presume perdoado, quando o cônjuge inocente, conhecendo-o, coabitar com o culpado -, cabe-lhe provar dois pontos: que o outro cônjuge conhecia o adultério e que, apesar disso, continuou a coabitar com ele. Não provando estes fatos não surgirá a alegada presunção.

O insigne Pontes de Miranda, em seus Comentários ao Código de Processo Civil, Rio, Forense, 1974, t. IV, pp. 235 e 236 ensina: «A presunção legal toma alguns elementos, fáceis de prova, e tem-nos como suficientes para que se considerem acontecidos, ou não acontecidos, outros elementos. No fundo, há prova indireta, posto que nem toda prova indireta se prenda a presunção: pode ser certa, sem qualquer alusão à simples probabilidade. A presunção simplifica a prova, porque a dispensa a respeito do que se presume. Se ela apenas inverte o ônus da prova, a indução, que a lei contém, pode ser elidida, in concreto e in hypothesi. Se ao legislador parece que a probabilidade contrária ao que se presume é extremamente pequena, ou que as discussões sobre provas seriam desaconselhadas, concebe-as ele como presunções inelidíveis, irrefragáveis: tem-se por notório o que pode ser falso. A confusão das ficções $\mathrm{com}$ as presunções ainda se nota em W. Endemann e Adolf Wach em (Das deutsche Zivilprozess, III, 534, e Handbuch des deutschen Zivilprozessrechts, I, 302).

Do exposto se depreende que a citada regra, segundo a qual a presungão legal dispensa do ônus da prova aquele que a tem a favor, deve ser assim entendida: a) quem invoca a presunção legal não deve provar o fato presumido pela lei, mas, b) deverá provar os fatos nos quais a lei funda a presunção.

Segundo José Carlos Barbosa Moreira (Temas de Direito Processual, São Paulo, 1977, Saraiva, pp. 65-66) o Código de Processo vigente confunde presunção com ficção, empregando terminologia inexata.

Exemplo desse equívoco no entender de Barbosa Moreira, depara-se na redação do art. $343, \S 1^{\circ}$ do CPC de 1973 , referente à intimação da parte para prestar depoimento pessoal e às conseqüências do eventual não-comparecimento ou recusa de depor. Lê-se no texto legal: «A parte será intimada pessoalmente, constando do mandado que se presumirão confessados os fatos contra ela alegados, caso não compareça ou, comparecendo, se recuse a depor». Ora, é evidente diz o insigne processualista - que, se a parte não comparece, ou se recusa a prestar depoimento, de modo nenhum confessa: o fato da confissão, em tal hipótese, é fato que não se pode considerar senão como inexistente. Aqui não há qualquer «juízo de probabilidade»: estamos diante de algo que sabidamente não ocorre, e ao legislador não é dado «presumir» que ocorra. Nem é isso, aliás, que ele pretende: quer apenas atribuir um fato diverso (o não-comparecimento, ou a recusa a depor) os mesmos efeitos que decorreriam do fato não verificado (a confissão). Estamos, assim, em pleno domínio da ficção, e não é por acaso que se costuma falar a propósito de ficta confessio. Outro seria o enquadramento dogmático, vale notar, se a norma esta- 
tuísse que os fatos alegados contra a parte, nas hipóteses de não-comparecimento ou de recusa a depor, «se presumirão verdadeiros». Aí, sim, existiria reaImente presunção, i.e., equiparação de efeitos baseada em «juízo de probabilidade»; ao ver do legislador, se a parte, intimada a depor, se absteve de comparecer ou de prestar depoimento, esse modo de proceder, revelando o temor de ser inquirida, autorizaria a conclusão de que as alegaçôes do adversário espalham a verdade. Tal como está redigido o dispositivo, porém, o caso é de ficção, e não de presunção legal.

Também de ficção — são ainda ponderações de Barbosa Moreira - é outra hipótese em que o Código, incidindo no mesmo equívoco, usa a expressão «presumindo-se». $\dot{E}$ no art. 832, $2^{\text {a }}$ parte, onde se prevêem as conseqüências do não-cumprimento, pelo obrigado, da sentença que lhe imponha o reforço da caução: «Não sendo cumprida a sentença, cessarão os efeitos da caụ̧ão prestada, presumindo-se que o autor tenha desistido da ação ou o recorrente desistido do recurso». Entra pelos olhos a absoluta falta de correspondência entre o fato que se diz «presumido» e a realidade das coisas: não ocorre, é claro, desis. tência alguma; apenas se quer dar ao descumprimento da sentença efeito idêntico, no particular, ao que produziria a desistência, se ocorresse. Isso, porém, é mais que presumir: é fingir.

Feitas essas considerações dentro do direito pátrio, passaremos de imediato a estudar a matéria no direito estrangeiro.

\section{A presunção no Direito Comparado}

\section{Direito francês}

Segundo o art. 1.349 do CC francês -- «Presunções são conseqüências que a lei ou o magistrado tira de um fato conhecido para um fato desconhecido».

O Código francês inclui as presunções no número das provas e distingue-as em duas espécies: legais e ordinárias.

Nos termos do art. 1.350 do CC: «Presunção legal é a que por uma lei especial é ligada a certos atos ou a certos fatos que são: $1^{\circ}$ ) os atos que a lei declara nulos, por considerá-los feitos em fraude das suas disposições, de acordo com a sua simples qualidade; $2^{\circ}$ ) os casos em que a lei declara a propriedade ou a liberagão resultar de certas circunstâncias determinadas; $3^{\circ}$ ) a autoridade que a lei atribui à coisa julgada; $4^{\text {n }}$ ) a força que a lei dá à confissão da parte ou ao juramento.

Segundo o art. 1.352 do mesmo Código - «a presunção legal dispensa de toda a prova aquele em proveito de quem ela existe».

Nenhuma prova é admitida contra a presunção da lei, quando, com fundamento nessa presunção, ela anula certos atos ou denega 
ação em justiça, a não ser que tenha reservado a prova em contrário, e salvo o que será dito sobre o juramento e a confissão judicial».

Como exemplo podemos citar os arts. 312 e ss., 911, 1.099 e 1.351 todos do CC francês.

As presunções legais constituem antes dispensas de provas, do que modos de provas.

Estas presunções são de direito estrito. Não é completa a enumeraģão do art. 1.350. Há ainda outros casos de presunções, como os dos arts. 185 e 341 da lei civil francesa.

\section{Presunções juris e de jure}

Há presunções legais absolutas. Qualificam-se em presunções juris e de jure. Esta presunção legal é acompanhada de proibição feita ao adversário de lhe destruir o efeito pela prova do contrário.

São presunções invenciveis indubitáveis, no dizer de Fabreguettes. obra citada, p. 210 . O legislador atribuiu-lhes certeza absoluta, porque admite como certa a conseqüência de um princípio físico ou moral.

Interessantes os subsídios trazidos por Fabreguettes, à p. 211 de sua obra: «É por isso, dizem Aubry et Rau, que a presunção de filiação legítima resultante da máxima Pater, is est quem nuptiae demonstrant só pode ser combatida nas hipóteses previstas pelos arts. 312 e 313 do CC».

E prossegue: «dos arts. 312 e 319 do CC estabelecendo que o indivíduo concebido durante o casamento tem por pai o marido e que a filiação legítima se estabelece pelo ato de nascimento, resulta que o indivíduo, cujo ato de nascimento constata que tem por mãe uma mulher casada prova, por essa própria constatação, que tem por pai o marido dessa mulher. Pouco importa que no ato de nascimento a mulher casada seja mencionada pelo seu nome de solteira e que um individuo, que não é o marido, nele declare ser o pai da criança. Por um lado basta que a identidade da mãe possa ser reconhecida e, por outro lado, a declaração do pretenso pai natural, no que toca ao reconhecimento, é nula segundo o art. 335 do CC».

\section{Presunções simples}

Por vezes a lei, quando dispensa da obrigação da prova uma das partes, deixa à parte contrária o direito de restabelecer a verdade e destruir assim a presunção. Diz-se então que a presunđ̧ăo admite prova em contrário: é uma presunção juris tantum. Alciat citado por Fabreguettes definiu muito bem a presunção juris tantum: «Probabilis conjectura ex certo signo proveniens quoe alio non adducto pro veritate habeatur». O termo ex certo signo quer dizer indício certo. 


\section{Das presuncões que não são estabelecidas pela lei - \\ Das presuncões ordinárias}

Dispõe o art. 1.353 do CC francês: «As presunções que não são estabelecidas pela lei são confiadas às luzes e à prudência do magistrado, que só deve admitir as presuncões graves, precisas e concordantes, e nos casos somente em que a lei admite a prova testemunhal, a não ser que o ato seja impugnado por fraude ou por dolo» (grifamos).

Eis em resumo as regras estabelecidas pelo legislador: 19) O juiz, sob pena de censura da cour suprême, não deve admitir as presunções de fato senão nos casos em que a lei admite a prova testemunhal; $2^{\circ}$ ) Quando um ato é argüido de fraude e dolo, o juiz pode sempre admitir as presunções; $3^{\circ}$ ) Uma única presunção é bastante (Demolombe, $\left.n^{\circ} 245\right)$; $4^{\circ}$ ) Toda a presunção deve ser grave, precisa e concordante. Sobre esse item ver atrás este nosso estudo, onde transcrevemos a lição de Carvalho Santos, em seu Código de Processo Civil Interpretado.

\section{Direito italiano}

O CC italiano tratou das presunções em seus arts. 2.727, 2.728 e 2.729. Dispõe o primeiro desses dispositivos: «Art. 2.727 (noção) As presunções são as conseqüências que a lei ou o juiz tira de um fato notório para chegar a um fato ignorado».

Vejamos agora, o art. 2.728 que reza in verbis: «Art. 2.728 (prova contra as presunções legais). As presunções legais dispensam de qualquer prova aqueles em favor dos quais são estabelecidas. Contra as presunções com fundamento nas quais a lei declara nulos certos atos ou não admite ação em juízo, não pode ser feita prova em contrário, a não ser que esta seja consentida pela pröpria lei».

Finalmente o art. 2.729 do CC italiano assim dispõe: «Art. 2.729 (presunçōes simples). As presunções não estabelecidas pela lei são dejxadas ao critério do juiz, o qual só deve admitir presunções graves, precisas e concordantes. As presunções não se podem admitir nos casos em que a lei exclui a prova por testemunhas».

Como se pode notar o Código Civil italiano recebeu uma grande influência do Código Civil francês, no que tange às presunções. Aliás Virgílio Andrioli, in Novissime Digesto Italiano, verbe «presunzioni», vol. XIII, p. 766 assim se manifesta: «La sostanza della normativa disciplinatrice delle presunzioni contenuta negli arts. 2.727-29 C. Civ., non differisce dagli arts. 1.349-54 C. Civ. del 1865, il quale, a sua volta, si riallaccia al Codice Civile francese (arts. 1.349-53)».

Prossegue Andrioli dizendo que: «L'art 2.727 è una norma a contenuto formale perchè non indica le conseguenze, che la legge o il giudice trae, ma si limita a delineare il rapporto tra fatto noto e fatto 
ignoto riproducendo la nota struttura del procedimento dedutivo, e norme a contenuto formale crano gli art. 1.349 del Codice del 1865 e 1.349 del Codice francese, che lo ha preceduto».

Nesse mesmo verbete «presunzioni», Andrioli faz uma análise das presunções legais absolutas, das presunções legais relativas e das presunções simples.

Como exemplos das presuncióes absolutas menciona os arts. 599 e 238 do CC. Pela importância merece ser transcrito este último: «Art. 238 (termo de nascimento conforme a posse de estado) - Com exceção do que se acha disposto no artigo seguinte, ninguém pode reclamar um estado contrário àquele que lhe atribuem o termo de nascimento de filho legítimo e a posse de estado conforme o próprio termo. Igualmente não pode ser contestada a legitimidade daquele que tem uma posse de estado de acordo com o termo de nascimento».

No que tange as presunções legais relativas acentua que tem sido longamente discutido pela doutrina se as presunções são instiutos do direito processual ou do direito substancial. Diz o professor peninsular in verbis: «Si è lungamente discusso sul se le presunzioni siano istituti del diritto processuale ovvero del diritto sostanziale (G. Chiovenda, Principi, p. 791; G. A. Micheli, L'onere della prova, Padova, 1942, p. 168), ma questa, como ogni altra questione di regolamento di confini, è stucchevole; se le disposizioni sulla ripartizione dell'onere della prova hanno per immediato destinatario il giudice e sol per indiretti interessati le parti, non sembra negabile il carattere processuale delle norme che disciplinano le presunzioni legali relative, laddove a diverso risultato perviene chi, capovolgendo la prospecttiva, ravvisa nelle parti gli immediati destinatari di dette norme» (grifos nossos).

A seguir, Andrioli menciona vários artigos do Código Civil, onde são encontradas presunções relativas. Assim, exemplificativamente temos: a) art. 880 (presunção de comunhão da parede divisória); b) art. 881 (presunção de propriedade exclusiva da parede divisória). Diz Andrioli: «Gli arts. 880 e 881 C. Civ., che prevedono l'uno la presunzione di comunione e l'aitro la presunzione di proprietà del muro divisorio, delineano temi di prova di estremo interesse»; c) art. 1.141 (mudança da detenção em posse); d) art. 1.142 (presunção de posse intermediária); e) art. 1.143 (presunção de posse anterior).

Pela natureza desse nosso estudo, que vem procurando ser o mais objetivo possível, deixaremos de transcrever os artigos acima citados.

Andrioli ainda cita como exemplos de presunções relativas os arts. 1.767 e 1.709 do CC. O primeiro deles diz respeito a presunção de gratuidade do depósito, e o segundo se refere à presunção de onerosidade do mandato.

Como já dissemos anteriormente, citando o próprio Andrioli, o Código Civil italiano de 1942 seguiu as normas e diretrizes do Código 
de 1865. E para provar nossa assertiva é só examinar o Manuale delle prove in materia civile, de Carlo Lessona, Firenze, Fratelli Cammelli, 1898, que no seu capítulo sobre as presunçôes simples, pp. 197 a 202, faz uma análise sobre as presunções legais, fixando as diferenças entre estas e as simples, encerrando seu trabalho expondo o valor probatório das presunções simples.

Assim ensinava Lessona: «Le presunzioni semplici non hanno valore, se non quando siano gravi, precise, concordanti. Basta che il giudice di merito negli loro uno di questi caratteri, e potrà senz'altro rifiutarsi a tenerne conto. Ma il giudice che le reputi fornite di quei caratteri, può dare loro il valore che crede, cioè reputarle prova, piena, o semplice principio di prova».

E concluiu Lessona: «La legge vuole che il giudice non apprezzi se non presunzioni gravi, precise e concordanti: ma ciò non toglie che anche una sola presunzione sia ammissibile, cioè valutabile: la legge contempla l'ipotese più comune, ma, come più non vigé la regola testis unus testis nullus, cosi non vige il divieto difondarsi su di una sola presunzione (Bonnier, Mattirolo, Ramponi)».

Como se vê o Código de 1942 manteve em seus artigos, as regras dos arts. 1.349-1.354 do CC de 1865 .

\section{Direito espanhol}

O Código Civil espanhol em seus arts. 1.259 e seguintes regula as presunções.

Como diz Valentin Silva Melero, obra citada, p. 117 «es de notar que el artículo 1.225 del Código anterior al vigente definía las presunciones «como inducciones que la Ley o el Juez sacan de un hecho conocido para juzgar otro desconocido».

$\mathrm{E}$ prossegue Silva Melero: «En este aspecto, pues, a las simples las calificaba de judiciales, por no estar sujetas a otras reglas que las del criterio humano, y ser sólo admisibles en los casos en que tenía lugar la prueba testimonial. En realidad aquel precepto seguía la ruta del artículo 1.353 del Código de Napoleón, que más expresivo, imponia la no admisibilidad de las presunciones hominis si no eran graves, precisas y concordantes, y que Garcia Goyena concretaba en la frase de «que estas presunciones debían quedar abandonadas a la ilustración y prudencia del Magistrado» (grifos nossos).

Vejamos alguns artigos do Código Civil espanhol que cuidaram das presunções: a) presunções de morte (arts. 33, 34 e 195); b) da legitimidade dos filhos (arts. 188 a 210); c) da boa fé (arts. 69, 434 e 436); d) dos direitos dos tutores (art. 267); e) da propriedade (art. 359); f) da participação em bens comuns (art. 393); g) presunções em matéria de posse nos (arts. 434, 436, 448, 449 e 459); h) em matéria de testamento cerrado com a quebra do lacre (art. 742); i) em erro no pagamento (art. 1.901). 
Poderíamos enumerar muitos outros casos, mas entendemos que os já mencionados são suficientes para este estudo.

\section{Direito alemão}

Dispõe o $\S 292$ do ZPO: «Cuando la ley establezea una presunción de existencia de un hecho, se permitirá la prueba de lo contrario si la ley no dispusiere otra cosa. Tal prueba se podrá aportar incluso mediante petición de interrogatorio de la parte, conforme al § 445».

James Goldschmidt em seu Derecho Procesal Civil, traduzido por Leonardo Prieto Castro, Barcelona, Labor, 1936, diz às pp. 259 e 260 que «tão pouco estão necessitados de prova os fatos que têm em seu favor uma presunção legal» (uma praesumptio iuris, § 292).

$\mathrm{E}$ prossegue Goldschmidt in verbis: Las presunciones legales son reglas jurídicas del Derecho justicial materiai que obligan a deducir de un hecho otro hecho (por ej. los $\S \S 484$ y 1.591 do BGB); o un derecho (por ej. 891, 1.006, 1.362 do BGB); mientras no se demuestre lo contrario».

Continua Goldschmidt dizendo que as presunções legais se diferenciam das normas de prova legal, em que estas regulam a força probatória de um meio de prova, enquanto que aquelas regulam a força probatória de um meio de prova, enquanto que aquelas regulam a força probatória de um fato que teria de se provar. Por conseguinte, toda presunção legal significa uma prova de indícios, fortalecida com a atribuição de força probatória em virtude da Lei.

Conclui Goldschmidt seu pensamento esclarecendo que devem diferenciar-se as presunções legais das presunções naturais, cuja força probatória não repousa na Lei, senão nas normas da experiência. As presunçbes naturais se referem por exemplo, a existência de capacidade processual, ao caráter causal de determinada conduta, etc. As presunções naturais não invertem tampouco como as legais o ônus da prova.

Ademais, deve delimitar-se o conceito das presunções legais frente a das irrefutáveis (iuris et de iure). $\mathrm{E}$ como exemplo dessas últimas temos os $\S \S 39,269,551,877$ e 1.591 do BGB.

\section{A presunção na Jurisprudência}

Levantamos em nosso direito pretoriano os seguintes acórdãos que cuidaram da matéria:

1. TJSP — 20-8-71 -- AC 200.598 - 6 Câm., Votação unânime.

Simulacão - Legítimo interesse de terceiros interessados em argüir a simulação - Prova do ato simulado in fraudem creditorum - A causa simulante - Evidência da alienação simulada in 
fraudem creditorum e o nexo causal entre ela e a iminência da ação dos credores do alienante - Ação julgada procedente.

Prova - Presunção - Só se devem admitir presunções graves, precisas e concordantes e só nos casos em que a lei admite a prova testemunhal - Um único indício, a tal ponto grave, pode formar a convicção do juiz (RJTJSP 18/130).

2. TASP - 5-11-70 — AC 139.971 — 6 Câmara - Votação unânime.

Ação - Nome - Transformação de ação pauliana em simulatória - Possibilidade.

Simulatória - Simulação evidenciada - Insolvência comprovada dos devedores - Transmissão de propriedade quando já pendiam várias ações ajuizadas pelo próprio autor - Arts. 147, $\Pi$ do CC e 252 do CPC (1939) - Ad̦ão procedente, embora proposta como revocatória. TASP (Cível) 14/73.

3. TJSP - 16-5-67 - Ap. Cível 161.564 - 1? Câmara - Votação unânime.

Responsabilidade civil - Prova insuficiente para a procedência da ação e prova produzida no Juízo Criminal - Prova circunstancial desacompanhada de outros elementos - Ação improcedente. Na esfera do livre convencimento do julgador deve ser considerado o elemento circunstancial desde que outros elementos também existam para demonstrar a verossimilhança dos fatos alegados - Já se tem dito que a prova circunstancial «acabou por se tornar praticamente inoperante» - Nem tanto assim - Mas para que opere há de entrosar-se com outros elementos convergentes para a mesma convicção (RJTSP 2/114).

4. TJSP - 8-6-61 - Ap. 107.154 - 3 Câmara.

Ato jurídico - Dolo - Prova - Embora indubitável que o dolo possa ser provado através de presunções estas devem ser graves, precisas e concordantes para determinar a nulidade do ato jurídico (RF 205/182).

5. TASP $-11-8-53$.

Prova - Indícios e presunções - Promissórias perfeitamente formalizadas que corresponderiam a juros usuários - Inexistência de outro meio de prova - Argüição repelida - Da aplicação do art. 252 do CPC. Tratando-se de títulos formais, completos, autônomos, cuja validade se ataca, mister se faz que os indícios se coordenem e avultem de tal maneira que concludente e incontestável se apresente a presunção neles procurada (RT 219/412).

6. TASP - 25-11-53.

Transporte de passageiro - ônibus - Perda de bagagem Ação de indenização procedente - Prova do valor da coisa perdida por meio de indícios e presunções. 
Responsabilidade civil - Transporte de passageiros - Perda de bagagem - Ação de indenização procedente.

Prova - Indícios e presunções - Valor da bagagem perdida -. Admissibilidade - Aplicação do art. 136, V do CC e do art. 253 do CPC - Não se tendo dado valor à mala extraviada, nem se tendo feito uma relação das coisas que ela continha, poderá o caso ser solucionado por presunções que são também meio de prova, resultantes as mais das vezes de indícios, na apreciação dos quais o juiz considerará livremente a natureza do negócio, a reputação dos indiciados e a verossimilhança dos fatos alegados na inicial e na defesa (RT 220/417).

7. TJSP $-30-4-53$.

Recurso - Agravo no auto do processo - Interposição pela parte que a final não apelou - Não conhecimento.

Casamento putativo - Casal que procurou regularizar, pelo matrimônio, uma situação de concubinato - Averbação de sentença inexistente de anulação do casamento anterior da mulher - Providências tomadas pelo nubente, que se incumbiu também da habilitação e do preparo dos papéis para o novo consórcio Má fé atribuída à esposa, que teria ocultado, a situação real Inexistência - Ação de anulação ajuizada pela progenitora do cônjuge varão, após a sua morte - ônus da prova a seu cargo - Pedido improcedente - Aplicação do art. 221 do CC.

Prova - Indícios e circunstâncias - Admissibilidade para demonstração da má fé - Objetivo não colimado - Casamento considerado putativo. Não se conhece de agravo no auto do processo interposto pelo litigante que a final não apelou - No casamento putativo a boa fé se presume, cumprindo à parte que a nega o ônus da prova - O direito tem admitido, sem vacilações, a prova semipilena, indireta, circunstancial e indiciária, estando atualmente o princípio integrado em nossa legislação (RT 214/141).

\section{Conclusões}

Do estudo que fizemos, procuramos analisar a matéria sob vários ângulos. Assim, pesquisamos o instituto das presunções desde o direito romano até os dias de hoje.

Trouxemos subsídios de várias legislações estrangeiras, como a francesa, italiana, espanhola e alemã.

Expusemos com alguma minúcia as várias doutrinas a respeito do assunto. Mostramos também a influência das teorias alienígenas nos Códigos de 1939 e de 1973 e na jurisprudência dominante de nossos tribunais. 
Enfim, sem nos alongarmos em extensas considerações, pois, fugiria à objetividade do trabalho, tentamos dar uma visão global da matéria em todas as suas nuances.

Mas, ainda aqui ficaria a pergunta: seria a presunção instituto de direito material ou de direito processual?

Para Chiovenda, as presunções relativas (iuris tantum) não têm caráter processual, nem atuam no processo civil, porque aparecem determinadas por razões de direito substantivo. Indagaríamos ainda: seria esta uma posição isolada, ou conta ela com um grande número de adeptos?

Dizemos isto porque o Direito italiano, apesar de dedicar em seu Código Civil, um capítulo sobre as presunções (arts. 2.727-29), não deixou de inserir também em seu Código de Processo Civil, regras sobre a matéria.

Com efeito, dispõe o art. 192 do CPC italiano: «ll giudice valuta il resultato della prova secondo il suo libero convincimento, salvo che la legge disponga diversamente. Il comportamento stesso delle parti può costituire elemento di convinzione».

Como se vê, o Direito italiano cuida das presungóes tanto em seu Direito Civil, como no Processual.

E não é só. A disposição do art. 253 do CPC 1939 é uma aplicação especializada do princípio geral, expressamente consagrado no Código, da livre avaliação da prova pelo juiz, conforme o disposto no art. 118 do mesmo ordenamento de 1939.

O Código de Processo Civil alemão (ZPO) também dispensou vários parágrafos para tratar das presunções. Pela importância, pedimos vênia, para transcrever o de número 286: «El tribunal tenendo en cuenta todos los elementos que hayan proporcionado las discusiones orales sobre el negocio y los resultados de la prueba que se haya ejecutado, resolverá según su libre convicción acerca de si debe tenerse por verdadera o no cada alegación de hecho de las partes. En la sentencia se indicarán los fundamentos y motivos de la convicción dei tribunal. Este no estará sujeto a reglas legales sobre la prueba más que en los casos señalados en esta ley».

Encerrando diríamos que são de grande importância as presunções na teoria da prova. Tanto é verdade, que Carnelutti em sua obra La prueba civil (traduzida por Niceto - Alcalá-Zamora y Castillo, Buenos Aires, 1944), dedica várias páginas no estudo das presunçiōes.

Se não, vejamos. O problema das fontes de presunções, ou simplesmente presunções, como disse mais tarde, preocupou largamente o pensamento de Carnelutti, em duas direções: formação do conceito e sistematização do mesmo. 
Acerca do primeiro desses pontos, aprecia um notável desnível entre o exame da prova histórica e da prova crítica, no sentido de que enquanto o campo da primeira se encontra notadamente dominada pela distinção entre prova testemunhal e prova documental, no campo da segunda reina todavia, o caos; a única distinção que se tem conseguido formular entre as provas críticas não se referem nem a sua estrutura nem a sua função, mas, tão-somente à sua eficácia legal, que serve para separar as presunções simples das presunções legais.

Na obra Lezioni di Dir. Proc. Civ., vol. III, também de Carnelutti, se estuda profundamente as regras legais da prova crítica e especialmente a propósito das presunções legais absolutas, onde se defronta o problema de sua ambígua natureza, situada entre o direito processual e o material (p. 334 e ss.).

Pela importância merece ser transcrito o ensinamento de Carnelutti, à p. 340 de suas Lexioni, numa tradução livre que fizemos: «Creio que se possa tranqüilamente concluir que a presunção legal absoluta está sempre fora do campo processual, no sentido de que o fato, que a determina, não tem nem a função da prova, mas constitui pelo contrário um fato jurídico material, ao qual a lei dá um efeito em consideração de um outro fato (fato presumido), que segundo a experiência o acompanha. A presunção legal absoluta torna-se então uma categoria histórica além de uma categoria lógica do direito; podem ser indicadas com este nome algumas normas para significar-se que foram formadas mediante a transformação de presunções legais relativas, com respeito às quais acaba por cair a faculdade da prova contrária, como ocorre provavelmente com as presunções previstas nos parágrafos dos arts. 773 e 1.279 do CC (1865). Mas uma vez derrubada a prova contrária à presunção, isto é, a prova em sentido próprio, desaparece e a equivalência não é mais processual, mas material, no sentido de que o próprio legislador a considera para atribuir efeitos jurídicos ao fato, que gera a presunção, primordialmente ao fato presumido» (Lezioni di diritto processuale civile, Padova, Cedam, 1933, vol. III).

Vimos no decorrer dessa exposição, que se não fossem as presunções, muitas questões ficariam insolúveis, deixando o magistrado sem qualquer base para seu decisório, e este sendo falho, causaria danos irreparáveis às partes litigantes e ao próprio processo.

\section{Bibliografia}

ALEJANDRE, Juan Antonio. Temas de histeria del derecho; derecho primitivo y romanización juridica, Universidade de Sevilla, 1977.

amaral Santos, Moacyr. Prova Judiciária no Cível e Comercial, 3a ed., vol. V, Max Limonad, 1968.

americano, Jorge. Comentários ao Código de Processo Civil no Brasil, 2q ed., vol. 19, São Paulo, Saraiva, 1958. 
ANDRIOLI, Virgílio. Presunzioni in Novissimo Digesto Italiano, vol. XIII, Torino, Utet, 1966.

AUBRY et Rau. Cours de Droit Civil Francais, $4^{9}$ ad., Paris, 1869.

barbosa Moreira, José Carlos. Temas de Direito Processual, São Paulo, Saraiva, 1977.

BENTO de Faria, Antonio. Revista de Direito Civil, Comercial e Criminal, vol, 39, Fascículo II, fevereiro de 1916.

BRAGA da Cruz, Guilherme. o Direito subsidiário na história do direito português, Coimbra, 1975.

CABreros, Miguelez-Alonso. Código de Derecho Canónico bilingue y comentado, Mađrłd, MCMLI.

CARNELLI, Lorenzo. El hecho notorio, La Ley, Buenos Aires, 1944.

CARNELUTTI, Francesco. La prueba Civil, trad. de Niceto Alcalá-Zamora y Castillo, Arayú, Buenos Aires, 1955.

—. Lezioni di Diritti Processuale Civile, Padova, Cedam, vol. III, 1933.

Carvalho Santos, J. M. Código de Processo Civil Brasileiro Interpretado, $3^{\sharp}$ ed., vol. III, Freitas Bastos, 1946.

Chrovenda G. Principi di Diritto Processuale Civile, 4.

COPPOLA. Presunzione in Nuovo Digesto Italiano, vol. X, Torino, Utet, 1939.

DECCOT'TIGNIES, Roger. Les présomptions en droit privé, Paris, Pichun et Durand, 1950.

DELLA Rocca, Fernando. «De morali certitudine in sententia canonica», in Saggi di diritto processuale canonico, Padova, Cedam, 1961.

Demolomber, C. Cours de Code Napoléon, Paris, Auguste Durand \& Hachette et Cie, 1872.

ENGEL, Ludovico. Collegium Universi Juris Canonici antheac juxta triplex juris objectum partitum, nunc vero servato ordine, Decretalium... $8^{\mathrm{a}} \mathrm{ed.}$, Beneventi, 1742.

FABREGUETTES, M. P. «Da prova indireta - Das presunções legais humanas», publicada na Revista de Direito Civil, Comercial e Criminal, dirigida pelo Dr. Antonio Bento de Faria, vol. 39, Fasc. II, fev. de 1916.

GOLDSCHMIDT, James. Derecho procesal Civil, traduzido por Leonardo Prieto Castro con adiciones sobre la doctrina y la legislación espanhola por Niceto Alcalá-Zamora y Castillo, Barcelona, Labor, 1936.

Laurent, F. Principes de Droit Civil Français, $3^{q}$ ed., Paris, Librairie A. Maresca, Ainé, A. Chevalier Marescq, Sucesseur, 1878.

LF DUAREN. «De probationibus», in Opera Omnia, vol. 3, cap. IV, 1946.

LESSONA, Carlo. Manuale delle prove in materia civile, Firenze, Fratelli Cammelli, 1898.

LIMONGI França, Rubens. «Código Visigótico», verbete publicado na Enciclopédia Saraiva de Direito, vol. 15.

LOBo da Costa, Moacyr. o Agravo no Direito Lusitano, Rio, Borsoi, 1974.

LOPES, Moreno, D. Santiago. La prueba de indicios, Madrid, Lib. Victoriano Suarez, 1897.

MALAtesta, Nicola Framarino Dei. A Lógica das Provas em Matéria Criminal, trad. do J. Alves, $2^{\text {a }}$ ed.

MARQUES, José Frederico. Instituições de Direito Processual Civil, vol. III, Forense, Rio, 1959. 
Martins, Pedro Batista. Comentários ao Código de Processo Civil, 29 ed., vol. III, t. 2. Forense, Rio, 1960.

Melero, VALentin Silva. La Prueba Procesal, Madrid, Revista de Derecho Privado, 1963 , t. I.

MENOCHIUS, Jacobus. De praesumptionibus, conjecturis, signis et indiciis, comentario, 2 vols. Venetiis, 1617.

Pontes de Miranda, F. C. Comentários ao Código de Processo Civil, t. IV. Forense, Rio, 1974.

RAMPONI. Teoria Generale dell Presunzioni, 1890.

SANTOS, Moacyr Amaral. Comentários ao Código de Processo Civil, vol. IV, Forense, Rio, 1976.

SURGIK, Alisio. «Presunção absoluta e relativa», verbete publicado na Enciclopédia Saraiva de Direito, vol. 60 . 